\title{
Resveratrol and Its Human Metabolites-Effects on Metabolic Health and Obesity
}

\author{
Margherita Springer ${ }^{1,2}$ and Sofia Moco ${ }^{1, *(1)}$ \\ 1 Nestle Institute of Health Sciences, Nestle Research, EPFL Innovation Park, Building H, 1015 Lausanne, \\ Switzerland; margherita.springer@rd.nestle.com \\ 2 TUM Graduate School, Technical University of Munich, 85748 Munich, Germany \\ * Correspondence: sofia.moco@rd.nestle.com; Tel.: +41-21-632-6165
}

Received: 22 November 2018; Accepted: 8 January 2019; Published: 11 January 2019

\begin{abstract}
Resveratrol is one of the most widely studied polyphenols and it has been assigned a plethora of metabolic effects with potential health benefits. Given its low bioavailability and extensive metabolism, clinical studies using resveratrol have not always replicated in vitro observations. In this review, we discuss human metabolism and biotransformation of resveratrol, and reported molecular mechanisms of action, within the context of metabolic health and obesity. Resveratrol has been described as mimicking caloric restriction, leading to improved exercise performance and insulin sensitivity (increasing energy expenditure), as well as having a body fat-lowering effect by inhibiting adipogenesis, and increasing lipid mobilization in adipose tissue. These multi-organ effects place resveratrol as an anti-obesity bioactive of potential therapeutic use.
\end{abstract}

Keywords: resveratrol; polyphenols; metabolism; obesity; diabetes; metabolic pathways

\section{Introduction}

Resveratrol (3,5,4'-trihydroxy-trans-stilbene, RSV, Figure 1.1) is one of the most widely studied polyphenols with over ten thousand reports in the literature. This stilbene has attracted interest in popular culture over the years for its potential, yet often controversial, health benefits. RSV was first discovered in the roots of the white hellebore (Veratrum grandiflorum Loes. fil.) in 1939 [1], even though it is mostly recognized as the phytoalexin present in red wine [2]. When epidemiological studies showed the cardioprotective benefits of wine [3,4], the association with RSV followed [5], opening the field to a wealth of scientific research. RSV has since been identified as: being cancer chemoprotective [6], being anti-inflammatory [7], improving vascular function [8], extending the lifespan and ameliorating aging-related phenotypes [9,10], opposing the effects of a high calorie diet [11], mimicking the effects of calorie restriction [12], and improving cellular function and metabolic health in general [13].

Even though RSV has been widely studied both in vitro and in vivo, its mechanism of action across conditions and doses remains elusive. From the many effects elucidated in in vitro studies, most have failed to reproduce in vivo [14,15]. Reasons for such non-reproducibility among studies are diverse. One reason is its pharmacokinetics, as in humans RSV is highly absorbed orally $(\sim 70 \%)$, yet has poor systemic bioavailability ( 0.5\%) [16]. Rapid metabolism into RSV sulfate and glucuronide conjugates occurs, in addition to accumulation in tissues, as detected in radioactive trials and other studies [16-18]. Furthermore, a wide range of inter-individual responses upon oral ingestion of RSV is known in humans and is a common feature of many food bioactives $[19,20]$. Gut microbiota $[20,21]$ and genetic background [22,23], including enzyme regioselectivity [24], are some of the possible known sources of the variation in responses. In contrast, in vitro studies have described an array of 
mechanistic effects that generate controversy given the likely non-physiological concentrations used, as well as the omission of the contribution of RSV metabolites [25].<smiles>Oc1ccc(/C=C/c2cc(O)cc(O)c2)cc1</smiles><smiles>O=S(=O)(O)Oc1ccc(/C=C/c2cc(O)cc(O)c2)cc1/C=C/c1ccc(O)cc1</smiles>

2<smiles>O=S(=O)(O)Oc1ccc(/C=C/c2cc(O)cc(OS(=O)(=O)O)c2)cc1</smiles>

4<smiles>O=C(O)[C@H]1O[C@@H](Oc2cc(O)cc(/C=C/c3ccc(O)cc3)c2)[C@H](O)[C@H](O)[C@@H]1O</smiles>

5<smiles>O=C(O)[C@H]1O[C@@H](Oc2ccc(/C=C/c3cc(O)cc(O)c3)cc2)[C@H](O)[C@H](O)[C@H]1O</smiles><smiles>Oc1ccc(CCc2cc(O)cc(O)c2)cc1</smiles><smiles>Oc1ccc(/C=C/c2cccc(O)c2)cc1</smiles>

8<smiles>Oc1ccc(CCc2cccc(O)c2)cc1</smiles>

9

Figure 1. Resveratrol and reported human metabolites: (1) trans-resveratrol (RSV); (2) transresveratrol-3-O-sulfate; (3) trans-resveratrol-4'-O-sulfate;

(4) trans-resveratrol-3,4'-O-disulfate; (5) trans-resveratrol-3-O-glucuronide; (6) trans-resveratrol-4'-O-glucuronide; (7) dihydroresveratrol (DHR); (8) 3,4'-O-dihydroxy-trans-stilbene; and (9) lunularin (also see Table 1).

Obesity is rising worldwide and is mainly attributed to changes in lifestyle, including overconsumption of food and decreased physical activity [26]. When energy intake exceeds energy expenditure over prolonged periods, then an obesity phenotype can develop [27]. Obesity has major health effects, and increased BMI (body mass index) is a risk factor in the development of type 2 diabetes, cardiovascular disease, dyslipidemias, non-alcoholic fatty liver disease, gallstones, Alzheimer's disease and even certain cancers [26,27]. To reduce obesity, lifestyle changes and therapies are aimed at reducing energy consumption or increasing energy expenditure, or both, and/or by managing its side effects. This can be achieved by altering diet and increasing exercise. However not all individuals respond to these lifestyle changes, leading to surgery or drug therapies. For instance, RSV was shown to improve exercise endurance by significantly increasing aerobic capacity and consumption of oxygen in the gastrocnemius muscle in mice. RSV treatment induced oxidative phosphorylation and mitochondrial biogenesis by activating the peroxisome proliferator-activated receptor $\gamma$ coactivator (PGC1 $\alpha$ ) through nicotinamide dinucleotide (NAD)-dependent deacetylase sirtuin-1 (SIRT1) leading to improved insulin sensitivity [13]. In addition, RSV has body fat-lowering effects as demonstrated by its anti-lipolytic affect in human adipocytes [28], as well as by decreasing adipocyte size, increasing SIRT1 expression, lowering nuclear factor kappa-light-chain-enhancer of activated B cells (NF-kB) activation and improving insulin sensitivity in visceral white adipose tissue in mice [29]. 
Even though RSV has been widely studied and associated with many benefits, many open questions remain, such as: (i) the activity of RSV at the nanomolar range, or of its human metabolites at the low micromolar range; (ii) levels of accumulation of these in target tissues able to elicit a biological effect; (iii) given an oral dose which preferred organs will be target sites of activity in which conditions or diseases; (iv) in physiological conditions which and how many protein targets are modulated; (v) how do these effects reproduce among individuals and populations; and (vi), how can one modulate RSV therapeutically. In this review we specifically discuss the role of RSV metabolism to better understand the mechanism of action, with particular emphasis on its potential effects in managing metabolic health and obesity.

\section{Human Metabolism of Resveratrol}

Being a phytoalexin, RSV levels vary greatly among food sources, seasons and batches. Certain foods are naturally rich in RSV, such as wine, peanuts and selected teas; however, RSV content in dietary sources remains at the lower milligram range [30]. To dose higher levels of RSV, dietary supplements are available in the open market at recommended daily doses between high milligram and gram levels [31]. Once RSV enters the gastro-intestinal tract, it suffers rapid and extensive biotransformation, with distribution into various organs (Figure 2), leading to consequences for its bioavailability and activity.
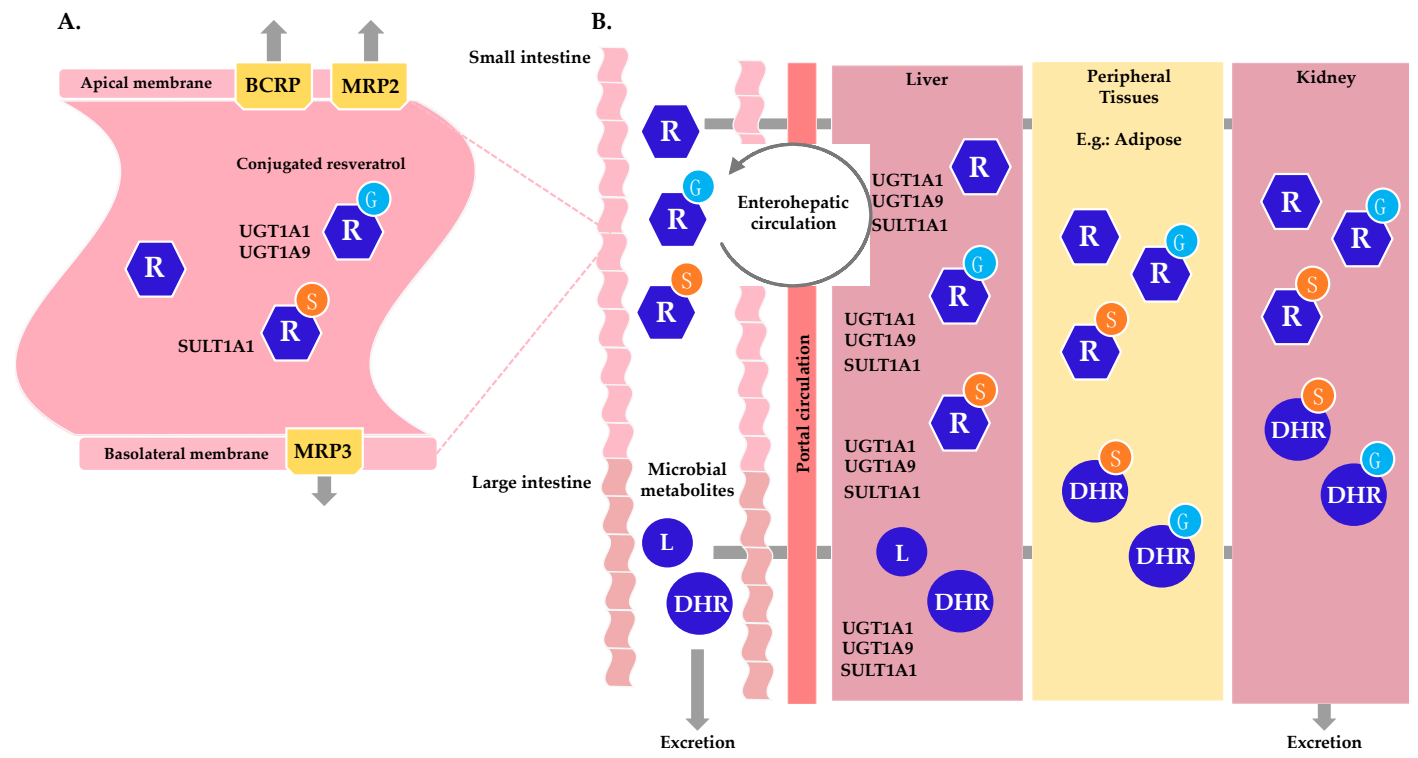

Figure 2. Metabolic fate and biotransformation of resveratrol in the human gastro-intestinal tract, and metabolism in different organs. (A) Metabolism of resveratrol (R) in the small intestine's enterocyte. Resveratrol is absorbed into the enterocyte and undergoes sulfation (S) by SULT1A1 and glucuronidation $(\mathrm{G})$ by UGT1A1 and UGTA9. Conjugated resveratrol exits the cell via BRCP and MRP2 transporters on the apical membrane and MRP3 on the basolateral membrane. A small faction of resveratrol escapes conjugation and exits the enterocyte via the basolateral membrane. (B) Integrated human metabolism of resveratrol. Resveratrol and conjugated metabolites exit the apical membrane of the small intestine and move towards the large intestine where they can be metabolized by the gut microbiota to generate dihydroresveratrol (DHR), lunularin (L) and 3,4'-dihydroxy-trans-stilbene (not shown). Resveratrol and metabolites that exit the enterocyte enter portal circulation. The liver expresses SULT1A1, UGT1A1 and UGTA9, which can further conjugate resveratrol. In addition, conjugated resveratrol and metabolites undergo enterohepatic circulation, leaving the liver to be reabsorbed in the intestine after hydrolysis, and entering portal circulation to reach the liver again for further metabolism. From the liver, resveratrol and metabolites enter systemic circulation and are absorbed by peripheral tissues, such as adipose tissue. The kidneys also participate in the metabolism of resveratrol, leading to excretion of polar resveratrol metabolites. 


\section{1. $R S V$ is Absorbed and Metabolized in Target Tissues}

The major function of the intestine is to digest food, making nutrients available for energy, while preventing the uptake of potentially harmful compounds. Bioactive compounds such as RSV can be perceived by the intestine as xenobiotics and therefore cross the intestinal epithelium to the blood via a transcellular pathway [32]. This route takes place through the enterocytes in the small intestine. Enterocytes, also known as absorptive epithelial cells, are the first site of reported RSV metabolism after being internalized by either passive diffusion [33] or carrier-mediated transport [32]. Once RSV is absorbed into the enterocyte, like other xenobiotics, it undergoes phase II of drug metabolism, producing polar metabolites, with easier excretion in the body. Specifically, RSV undergoes conjugation with sulfate (mediated by sulfotransferases, SULTs) and with glucuronate (mediated by uridine 5'-diphospho-glucuronosyltransferases, UGTs).

Drug metabolism takes place in multiple organs and cell types, and the observed biotransformation differs in metabolite levels [18], enzyme expression [34] and selectivity [24]. The superfamily of SULTs sulfates a broad spectrum of diverse endogenous and exogenous substrates. SULT1A1 is the main enzyme responsible for the transfer of a sulfate group to a hydroxyl group in phenolic compounds [35]. Biochemical studies have shown that, SULT1A1 is the main SULT responsible for the sulfation of RSV into RSV-3-O-sulfate (Figure 1.2), and to a minor extent SULT1A2, SULT1A3 and SULT1E1, whilst RSV-4'O-sulfate (Figure 1.3) is mainly produced by SULT1A2, and RSV-3,4'-O-disulfate (Figure 1.4) is mainly catalyzed by SULT1A2 and SULT1A3 [18,36], Table 1. Similar to the SULT family, UGT is also a large family of related enzymes involved in detoxification, which glucuronidate various substrates [37]. The glucuronidation of RSV is mainly catalyzed by UGT1A1 and UGT1A9, and to a minor extent by UGT1A6, UGT1A7, and UGT1A10 leading to RSV-3-O-glucuronide (Figure 1.5) and/or RSV-4'-O-glucuronide (Figure 1.6) [18], Table 1. In human tissues, the small intestine contains the highest amount of SULT proteins of any tissue, yet preferably expresses SULT1B1, followed by SULT1A3 and then SULT1A1 [34]. In the liver and kidney, however, SULT1A1 is the main SULT protein isoform expressed [34]. SULT1A1 was also recently found in adipocytes, and modulates RSV sulfation in the SGBS (Simpson-Golabi-Behmel syndrome) human adipocyte [28]. Again, the intestine is the human tissue with higher UGT1A content, largely expressing UGT1A10 and 1A1, while the kidney preferably expresses UGT1A9, and the liver expresses UGT1A4, 1A1, 1A6 and 1A9 at the protein level [38]. Of note is the inter-species variation of phase II metabolism in which RSV sulfates are the main conjugates in humans, while glucuronides are the preferred conjugates in pigs and rats [32]. More importantly, drug metabolism is a known cause of inter-individual variability, as both SULTs and UGTs have genetic polymorphisms [22,35]. From animal and human studies, RSV and metabolites thereof have been reported to reach many tissues and biofluids, Table 1 .

After absorption and conjugation, RSV sulfates and glucuronides have two fates: they can either be transported through the apical membrane and reach the intestinal lumen or they can pass through the basolateral membrane and enter the bloodstream (Figure 2A). On both membranes, the enterocyte contains ABC (ATP-binding cassette) transporters, which are part of a large family of transport proteins and are considered to be instrumental in drug absorption and response [39]. On the apical side, breast cancer resistance protein (BCRP/ABCG2), multidrug resistance-associated protein 2 (MRP2/ ABCC2), and P-glycoprotein (P-gp/MDR1/ABCB1) transporters are expressed, while on the basolateral side, MRP3 (ABCC3) is expressed instead. BCRP and MRP2 play a major role in the efflux of conjugated RSV, while P-gp plays a minor role. On the basolateral membrane, conjugated RSV is transported into blood capillaries by the ABC transporter MRP3 [32]. Transporters are not limited to playing a role in the absorption and distribution of RSV and metabolites in the small intestine, as they are also expressed in other tissues, such as the liver and kidneys [40]. When RSV and metabolites reach the bloodstream, they can be transported by binding to blood proteins such as lipoproteins [5], hemoglobin, and albumin, before reaching other tissues, such as liver, kidney and other peripheral tissues. 
Table 1. Human, rat, and mouse resveratrol metabolites after oral administration in different biofluids and tissues (see structures in Figure 1).

\begin{tabular}{|c|c|}
\hline Metabolite & Species and Tissue or Biofluid [Reference] \\
\hline trans-resveratrol & $\begin{array}{l}\text { Human: serum [41], plasma }[15,16,42], \text { urine }[16,20] \\
\text { Rat: plasma [43-45], liver [44], lung [44], brain [44], kidney [44] } \\
\text { Mouse: plasma [18,44,46], liver [18,44,46], lung [18,44], brain [44,46], } \\
\text { kidney [18,44], heart [18,46], stomach [18], duodenum [18], } \\
\text { intestine [18], muscle [18], spleen [18], thymus [18], urine [18], feces [18] }\end{array}$ \\
\hline trans-resveratrol-4'-O-glucuronide & $\begin{array}{l}\text { Human: serum [41], plasma [42], urine [42] } \\
\text { Mouse: plasma [46] }\end{array}$ \\
\hline trans-resveratrol-3-O-glucuronide & $\begin{array}{l}\text { Human: serum [41], plasma [42], urine [16,42] } \\
\text { Rat: plasma [43], liver [47], adipose tissue [47,48], skeletal muscle [47] } \\
\text { Mouse: plasma [18,46], liver [18,46], lung [18], brain [46], kidney [18], } \\
\text { heart [18,46], stomach [18], duodenum [18], intestine [18], muscle [18], } \\
\text { spleen [18], thymus [18], urine [18], feces [18] }\end{array}$ \\
\hline trans-resveratrol-diglucuronide & $\begin{array}{l}\text { Human: plasma [49], urine [49] } \\
\text { Mouse: plasma [46], liver [46] }\end{array}$ \\
\hline trans-resveratrol-3-O-sulfate & $\begin{array}{l}\text { Human: plasma [42], plasma [16], urine [16] } \\
\text { Rat: adipose tissue [47,48] } \\
\text { Mouse: plasma [18,46], liver [18,46], lung [18], brain [46], kidney [18], } \\
\text { heart [18,46], stomach [18], duodenum [18], intestine [18], muscle [18], } \\
\text { spleen [18], thymus [18], urine [18], feces [18] }\end{array}$ \\
\hline trans-resveratrol-4'-O-sulfate & $\begin{array}{l}\text { Human: plasma [42], plasma [16], urine }[16,42] \\
\text { Rat: liver [47], adipose tissue }[47,48]\end{array}$ \\
\hline cis-resveratrol-3-O-sulfate & Rat: adipose tissue $[47,48]$ \\
\hline trans-resveratrol-3, $4^{\prime}$-disulfate & $\begin{array}{l}\text { Human: plasma [42] } \\
\text { Rat: adipose tissue [48] } \\
\text { Mouse: plasma [18], liver [18], lung [18], kidney [18], heart [18], } \\
\text { stomach [18], duodenum [18], intestine [18], muscle [18], urine [18], } \\
\text { feces [18] }\end{array}$ \\
\hline trans-resveratrol-glucuronide-sulfate & Mouse: plasma [46], liver [46] \\
\hline dihydroresveratrol & $\begin{array}{l}\text { Human: urine [20], plasma [15] } \\
\text { Rat: liver [47], skeletal muscle [47] }\end{array}$ \\
\hline dihydroresveratrol-glucuronide & $\begin{array}{l}\text { Human: urine [16] } \\
\text { Rat: liver [47] } \\
\text { Mouse: plasma [46], liver [46] }\end{array}$ \\
\hline dihydroresveratrol-sulfate & $\begin{array}{l}\text { Human: urine [16] } \\
\text { Rat: liver [47], adipose tissue [47] } \\
\text { Mouse: plasma [46], liver [46] }\end{array}$ \\
\hline dihydroresveratrol-glucuronide-sulfate & Mouse: plasma [46] \\
\hline 3,4'-dihydroxy-trans-stilbene & Human: urine [20] \\
\hline lunularin & Human: urine [20] \\
\hline
\end{tabular}

\subsection{The Gut Microbiome Metabolizes RSV and RSV Influences Gut Microbial Composition}

RSV and the metabolites thereof can be further metabolized in the colon by the gut microbiota (Figure 2B). Here, RSV metabolites may be hydrolyzed, regenerating RSV, and additional reduction reactions may take place. The most described microbial metabolite of RSV is dihydroresveratrol (DHR, Figure 1.7, Table 1). Intestinal bacteria are able to metabolize RSV into DHR by reduction of the double bond between the two phenol rings. DHR produced by the intestinal bacteria can then be absorbed, conjugated and excreted in the urine. In addition to DHR, 3,4'-dihydroxy-trans-stilbene (Figure 1.8, Table 1) and lunularin (Figure 1.9, Table 1) have also been identified as gut metabolites of RSV in human urine. A large inter-individual variation between subjects was observed, in which some proved to be 
lunularin producers, DHR producers or mixed producers, according to levels of these metabolites [20]. Using 16s rRNA sequencing of fecal samples, lunularin producers were associated with a higher abundance of Bacteroidetes, Actinobacteria, Verrucomicrobia, and Cyanobacteria and a lower abundance of Firmicutes than either the DHR or mixed producers. The bacterial strains Slackia equolifaciens and Adlercreutzia equolifaciens, species not previously known to metabolize RSV, were found to metabolize RSV to DHR [20].

From the gut, RSV microbial metabolites may be absorbed and reach the liver as well as other tissues for further metabolism or excretion. A common feature of certain xenobiotics, including RSV, is the enterohepatic circulation, in which RSV metabolites may go from the liver to the bile and re-enter the intestine. From the small intestine, RSV and metabolites may suffer hydrolysis before reaching the portal circulation and being re-transported into the liver. The extensive presence of RSV and metabolites in the bloodstream can be attributed to enterohepatic circulation [16], Figure 2B.

Beyond the metabolic capacity of the gut microbiota to convert polyphenols such as RSV into often smaller and simpler molecules, the gut microbiota has been associated with other functions. The influence of gut microbiota on the metabolism of polyphenols, and conversely the modulation of the gut microbial composition due to polyphenol intake, are significant topics for understanding the metabolism and activity of these bioactives in humans [19,50]. RSV supplementation is known to alter the microbiome in at least two ways, by acting as an antimicrobial agent and through modulating gut microbial composition. Dao et al. reported that RSV-treated mice lacked three gut bacteria compared to controls: Parabacteroides jonsonii, Alistipes putredinis and Bacteroides vulgatus [51]. RSV increased levels of Bifidobacterium and Lactobacillus, while decreasing levels of Escherichia coli and Enterobacteria in RSV-treated rats [52]. The antimicrobial activity of RSV against $E$. coli lies in the inhibition of bacterial cell growth by suppressing FtsZ (filamenting temperature-sensitive mutant Z) expression and Z-ring formation, essential for cell division [53]. RSV has a wide range of antimicrobial activity, as it seems to be effective against both gram-positive and gram-negative pathogenic bacteria [54].

RSV supplementation can alter the gut microbial composition and some suggest this may be an essential mechanism of action of RSV [55]. RSV leads to functional changes in the gut microbiome of obese mice, including: decreased relative abundance of Turicibacteraceae, Moryella, Lachnospiraceae, and Akkermansia and increased relative abundance of Bacteroides and Parabacteroides. Glucose homeostasis in obese mice was improved by faecal transplantation from healthy RSV-fed donor mice [55]. Obese gut microbiota has been associated with a reduced Bacteroidetes/Firmicutes ratio in mice and humans [56] and RSV was found to increase this ratio in rodent studies [55,57]. Firmicutes, more prevalent in the obese, produce greater amounts of energy from dietary fiber than other major gut bacterial phyla, such as Bacteroidetes, by increasing the production of short chain fatty acids (SCFAs) [58]. Furthermore, an increase in the Bacteriodetes population in the gut was also observed in overweight men, upon RSV and epigallocatechin-3-gallate supplementation [59]. Bacteroidetes is also associated with postprandial fat oxidation [58]. In addition to SCFAs production, the gut microbiota produces many other small molecules. Dietary choline, L-carnitine and lecithin can be converted into trimethylamine in the gut, which is converted to trimethylamine- $N$-oxide (TMAO) in the liver. TMAO production is associated with chronic diseases like cardiovascular disease, type II diabetes, and obesity $[58,60]$. RSV supplementation was shown to reduce TMAO production by increasing the Bacteroidetes population in the gut of mice [61].

\subsection{Biotransformation of RSV Limits Plasma Bioavailability}

The metabolic fate of RSV in the body is therefore widespread into different tissues, and its metabolism is rapid and extensive. A preclinical study in rats demonstrated that only a small fraction of RSV $(1.5 \%)$ is able to escape conjugation and enter the bloodstream unmodified. About $75 \%$ enters the enterocyte while the remaining $25 \%$ is directly excreted. Once inside the cell, $60 \%$ is glucuronidated and $13.5 \%$ sulfated. These conjugates partially return to the intestine ( $42 \%$ glucuronides and $12 \%$ sulfates), leaving $17 \%$ glucuronides and $1.5 \%$ sulfates in the bloodstream $[32,62]$. Administering the 
metabolites RSV-3-O-sulfate (Figure 1.2) and RSV-4'-O-sulfate (Figure 1.3) to mice has shown that these metabolites are absorbed yet at low bioavailability (14\% and 3\%, respectively). Interestingly, regeneration of free RSV ( $2 \%$ ) into the bloodstream was observed, indicating in vivo hydrolysis of sulfates, depending on membrane transporter activities [63].

Many studies, both preclinical and clinical, have detected RSV metabolites in plasma (Table 1). Plasma concentration is an indicator of RSV bioavailability and determines the amount of RSV and metabolites available to peripheral target tissues. Regarding human studies, plasma concentration of RSV after single (Table 2) and repeated dosing (Table 3) was measured for studies from 2010 to 2018. Earlier studies have been reviewed already by Cottart et al. [64]. Administered in either single or repeated dosing, the peak levels of RSV in plasma were very low, given its poor bioavailability.

Table 2. Reported resveratrol plasma concentration in humans after a single dose of resveratrol (studies after 2010).

\begin{tabular}{|c|c|c|c|c|}
\hline $\begin{array}{c}\text { Number of Participants, } \\
\text { Characteristics }\end{array}$ & Dose (mg) & Administration & $\begin{array}{c}\text { Peak Plasma } \\
\text { Concentration }(\mathrm{ng} / \mathrm{mL})\end{array}$ & Reference \\
\hline 15 , healthy & 500 & Tablet & 71.18 & [65] \\
\hline $\begin{array}{l}\text { 6, low BMI } \\
\text { 6, high BMI }\end{array}$ & 2125 & Tablet and drink & $\begin{array}{l}634.32 \\
498.56\end{array}$ & [66] \\
\hline 7, healthy & 500 & Capsule $^{1}$ & 1598 & {$[67]$} \\
\hline 8-9/dose, healthy & $\begin{array}{l}250 \\
500\end{array}$ & Capsule & $\begin{array}{l}5.65 \\
14.4\end{array}$ & [68] \\
\hline 2 , healthy & 146 & Lozenge & 328.5 & [69] \\
\hline
\end{tabular}

Table 3. Reported resveratrol plasma concentration in humans after repeated doses of resveratrol (studies after 2010).

\begin{tabular}{|c|c|c|c|c|c|}
\hline $\begin{array}{c}\text { Number of Participants, } \\
\text { Characteristics, } \\
\text { Study Type }\end{array}$ & Dose (mg/day) & Days & Administration & $\begin{array}{l}\text { Peak Plasma } \\
\text { Concentration } \\
(\mathrm{ng} / \mathrm{mL})\end{array}$ & Reference \\
\hline $\begin{array}{l}\text { 6, low BMI } \\
6 \text {, high BMI }\end{array}$ & 2125 & 11 & $\begin{array}{l}\text { Tablet and } \\
\text { drink }\end{array}$ & $\begin{array}{l}903.0 \\
245.0\end{array}$ & [66] \\
\hline $\begin{array}{l}35 \text {, healthy males, } \\
\text { cross-over study }\end{array}$ & 800 & 5 & $\begin{array}{c}\text { Capsule } \\
\text { Dairy drink } \\
\text { Soy drink } \\
\text { Protein-free } \\
\text { drink }\end{array}$ & $\begin{array}{c}\text { Capsule: } 0.56 \\
\text { Dairy drink: } 0.61 \\
\text { Soy drink: } 0.58 \\
\text { Protein free drink: } 0.70\end{array}$ & [70] \\
\hline 7 , healthy & 500 & 28 & Capsule $^{1}$ & 2967.25 & [67] \\
\hline $\begin{array}{l}\text { 40, healthy, repeated } \\
\text { sequential dosing }\end{array}$ & $\begin{array}{c}500 \\
1000 \\
2500 \\
5000\end{array}$ & 29 & Caplet & $\begin{array}{l}43.8 \\
141 \\
331 \\
967\end{array}$ & [71] \\
\hline $\begin{array}{c}\text { 6, patients with hepatic } \\
\text { metastases, randomized } \\
\text { double-blind clinical } \\
\text { trial }\end{array}$ & 5000 & 14 & $\begin{array}{l}\text { Micronized } \\
\text { resveratrol } \\
\text { mixed in liquid }\end{array}$ & 1942 & [72] \\
\hline 8 , healthy subjects & 2000 & 7 & Capsule & 1274 & [73] \\
\hline $\begin{array}{l}\text { 19, overweight or obese, } \\
\text { randomized, } \\
\text { double-blind, } \\
\text { placebo-controlled, } \\
\text { crossover intervention }\end{array}$ & $\begin{array}{c}30 \\
90 \\
270\end{array}$ & 6 & Capsule & $\begin{array}{c}181.31 \\
532.00 \\
1232.16\end{array}$ & {$[74]$} \\
\hline
\end{tabular}

body mass index (BMI); ${ }^{1}$ Capsule also contained $10 \mathrm{mg}$ of piperine. 


\section{Molecular Action of Resveratrol and Metabolites}

\subsection{RSV Modulates a Panoply of Protein Targets}

Many and diverse effects have been described for RSV, indicating an array of possible protein targets that can be (in)directly modulated by this compound [75-80]. Recently, a computational approach was used to map all publically available polyphenol-protein interactions [81]. Among all polyphenols and human metabolites, RSV was found to be one of the polyphenols with the most known interactions with proteins (738 RSV-protein interactions). Only five protein interactions were reported with RSV metabolites, specifically interacting with DHR, highlighting the lack of studies on RSV metabolites. Taken together, the protein interactome of RSV and DHR led to 743 interactions (Figure 3). The interacting proteins can be classified in terms of diseases, using DAVID's [82] genetic association database (GAD) [83] disease classification system. RSV showed low coverage for most diseases $(<50 \%)$, yet a widespread representation, highlighting its potential pleotropic effect. RSV modulates genes within pathways of cancer, metabolic and cardiovascular diseases, and to lesser extent other disease classes (Figure 3A). Taking the same list of RSV-interacting proteins, these could be classified in terms of protein super-families, using the InterPro [84] protein classification in DAVID. This analysis highlighted an enrichment in many protein super-families modulated by RSV (Figure 3B), of relevance in metabolic diseases and obesity, such as nuclear hormone receptor-type (e.g., PPAR $\gamma$ ), insulin related, NF-kB, enolases, sirtuins, and nitric oxide related proteins. Using STITCH [85], a protein-metabolite database, proteins of experimental evidence were further selected to interact with RSV (Figure 3C). This obtained network highlighted, with substantial overlap, the enrichment of RSV-interacting proteins previously identified by InterPro classification (Figure 3B).

While RSV may establish a large number of possible interactions, some of these proteins are already established direct targets of RSV, at least in vitro [77]. The structure of some of these protein-RSV complexes can be found in the Protein Databank (PDB) [86], accounting for 24 RSV-protein complexes, and even a handful of RSV metabolite protein complexes.

\subsection{RSV Increases Energy Expenditure and Vascular Function}

One of the most studied mechanisms of RSV is its capacity to increase energy expenditure by modulating protein targets within central energy pathways and signaling, specifically by inducing mitochondrial biogenesis. RSV can directly activate SIRT1 and SIRT5. Because sirtuins are NAD-dependent deacetylases, they directly depend on $\mathrm{NAD}^{+}$and therefore are quite sensitive to cellular energy via imbalances of the redox pair $\mathrm{NAD}^{+} / \mathrm{NADH}$. Sirtuins act as caloric restriction mimetics, with potential benefits in longevity and preventing age-related complications, as well as type II diabetes and obesity. By activating SIRT1, RSV elicits deacetylation of PGC1 $\alpha$, a key regulator of energy metabolism, leading to decreased glycolysis in muscle and the liver, and increased lipid use $[13,87]$. In addition, RSV inhibits ATP production by interfering with mitochondrial function, leading to an increase of AMP/ATP ratio, which activates AMP-activated protein kinase (AMPK) [75]. AMPK is a pivotal protein in governing energy homeostasis and its activation takes place in cases of nutrient starvation or in the presence of agonists, such as certain drugs (e.g., metformin) or natural compounds such as RSV. Furthermore, AMPK may inhibit mTOR signaling, that in certain species has been associated with an extended lifespan, given its anti-ageing effects. The signaling pathway of AMPK crosstalks with Akt (protein kinase B). Akt are kinases involved in metabolism and cell proliferation and are part of the PI3K/AKT/mTOR pathway that governs the cell cycle. Activation of Akt reduces the activity of AMPK through direct phosphorylation [79].

Interestingly, AMPK and Akt have been shown to directly phosphorylate the endothelial nitric oxide synthase (eNOS). eNOS, responsible for the production of nitric oxide (NO), is activated by shear stress and agonists, and has a protective function in the cardiovascular system. RSV has been shown to be such an agonist, by improving vascular function and vasoprotective effects, including vascular 
NO production and bioavailability, and perivascular adipose tissue function [88]. Akt and AMPK may contribute to the stimulation of NO production by eNOS in response to RSV treatment [79].

A

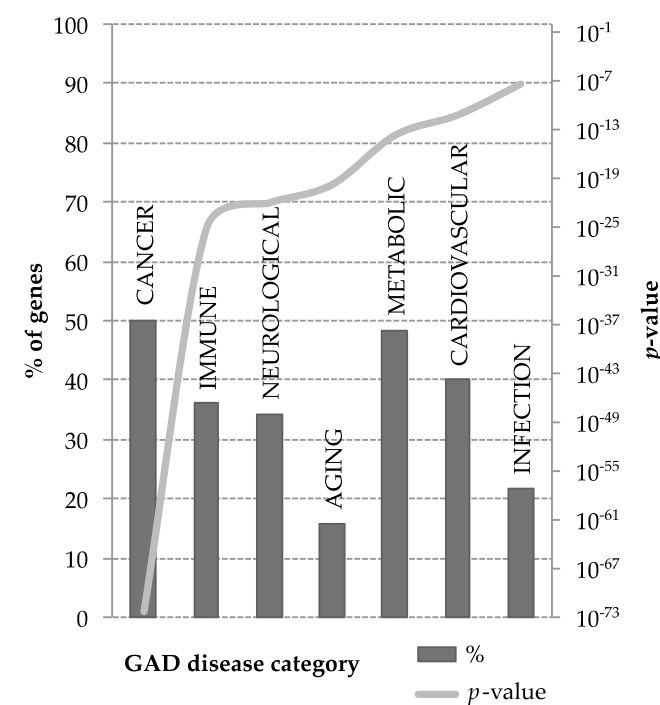

C

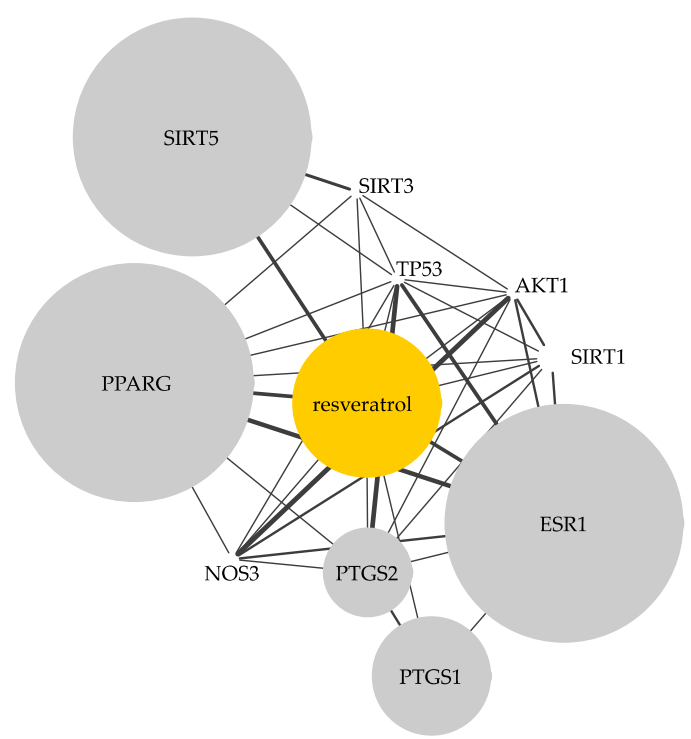

B

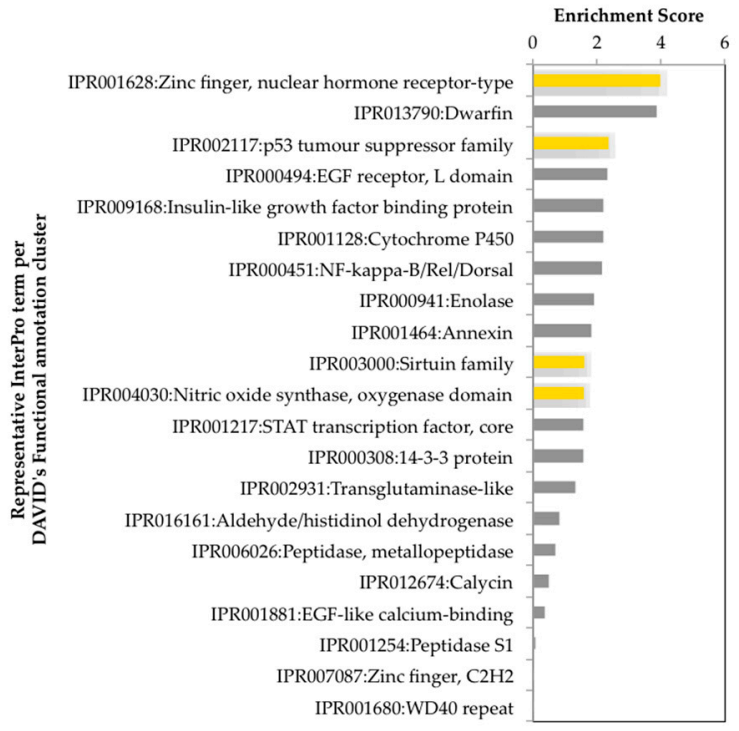

Figure 3. Using Lacroix et al.'s [81] human polyphenol-protein interactome, proteins (743) interacting with resveratrol and dihydroresveratrol were functionally analyzed in DAVID [82]. (A) Resveratrol interacting genes annotated according to the genetic association database (GAD) [83] disease categories, according to percentage of genes and $p$-value. (B) Clustering of protein super-families according to the InterPro [84] protein classification, at the highest stringency (in yellow, protein classes represented in (C). (C), Human resveratrol-protein interactome using experimental evidence obtained from STITCH [89]. The size of the node reflects the strength of the resveratrol-protein interaction. Depicted proteins: peroxisome proliferator-activated receptor gamma (PPARG), NAD-dependent deacetylase sirtuin-1 (SIRT1), 3 (SIRT3) and 5 (SIRT5), nitric oxide synthase 3 (NOS3), prostaglandin-endoperoxide synthase 1 (PTGS1) and 2 (PTGS2), estrogen receptor 1 (ESR1), tumor protein p53 (TP53), and AKT serine/threonine kinase 1 (AKT1). 
Beyond central metabolism and bioenergetics, RSV also impacts lipid metabolism. RSV can directly inhibit PPAR $\gamma$, a nuclear receptor expressed in adipose tissue, or do so indirectly via SIRT1, leading to decreased adipogenesis and increased lipolysis [87]. SIRT1 is also known to repress NF-kB activity, and thereby reduce inflammation. RSV modulates inflammation by directly interacting with cyclooxygenases (COX), which catalyze the formation of prostaglandins, bioactive lipids with hormone-like effects [77].

\subsection{Effect of RSV on Epigenietics}

While RSV has an impact on metabolism, some of its mechanisms are a consequence of epigenetic modifications. In fact, RSV can induce epigenetic modifications to the DNA sequence. Epigenetic modifications include DNA methylation, histone modifications and nucleosome positioning. These modifications can interact with each other to influence gene expression [90]. RSV supplementation can influence DNA methylation and histone modification, with the latter being most relevant in the context of obesity and energy balance. Histones are subject to post-transcriptional modification like methylation, phosphorylation, ubiquitination, SUMOylation and ADP-ribosylation. These modifications can be reversed by methyltransferases, histone demethylases, kinases, histone acetyltransferases and histone deacetylases. For instance, RSV can influence histone deacetylation via sirtuins, and sirtuins activated by RSV can deacetylate sites on PGC1 $\alpha$ [13]. The nuclear bile acid receptor farnesoid X receptor (FXR) is a target a SIRT1 that plays a critical role in the regulation of lipid and glucose metabolism. RSV treatment reduced acetylated FXR levels, with benefits for metabolic health [91].

\subsection{RSV Influences Redox Metabolism}

RSV has 16-times lower antioxidant capacity than alpha-tocopherol [92], nature's ubiquitous antioxidant, and therefore will be inefficient per se for radical scavenging in physiological conditions. However RSV, in addition to other polyphenols, has been described as undergoing redox cycling, being able to adopt a quinone-like structure and generate reactive oxygen species (ROS). ROS production leads to the activation of the nuclear factor-erythroid 2-related factor-2 (Nrf2), a transcription factor that regulates redox status, and reacts against stresses. In addition, Nrf2 improves cellular recycling and cross-talks with central and lipid metabolism, as well as modulates phase I and II metabolism enzymes and transporters $[93,94]$. One of these phase II detoxifying enzymes, quinone reductase 2 (QR2) has been shown to interact directly with RSV. The inhibition of QR2 by RSV may induce other cellular antioxidant enzymes and increase cellular resistance to oxidative stress [77]. Oxidative stress contributes to type II diabetes, and RSV showed antioxidant effects after eight weeks of supplementation with $800 \mathrm{mg} /$ day in the blood and PBMCs (peripheral blood mononuclear cells) of diabetic patients. After RSV consumption, the expression of Nrf2 and superoxide dismutase (SOD) was significantly increased, along with reductions in body weight, BMI and blood pressure [95].

\subsection{RSV Metabolites Exhibit Activity}

RSV metabolites have been examined for their potential activity only recently. A biochemical study compared the action of RSV, and RSV-3- and 4'-O-sulfates (Figure 1.2,3) on three direct targets: COX, SIRT1 and QR2. RSV and metabolites can inhibit both COX and QR2 enzymes. SIRT1 is activated by RSV and metabolites, but the activation seems to be a substrate-dependent phenomenon questioning in vivo relevance [96]. Comparable in vitro activities were also found for RSV glucuronides [97]. The ability to bind to human serum albumin was found to be comparable between RSV, RSV-4'-glucuronide (Figure 1.6) and DHR (Figure 1.7), while RSV-3-O-glucuronide (Figure 1.5) showed a slightly lower affinity. RSV-4'-glucuronide was able to inhibit COX-2 and DHR presented comparable activity in inhibiting NO production [97]. The metabolites RSV-3- and 4 '-O-sulfates were also studied in vivo, by dosing these conjugates directly to mice. Both compounds led to low bioavailability, but hydrolysis of sulfate moieties was identified, contributing to the 
recirculation of free RSV. In human cancer cells, RSV metabolites partially regenerated free RSV and prompted autophagy and senescence [63]. Thus, these studies lead to the suggestion of a metabolic interplay between RSV and phase II metabolites in the body. According to the cell's specific conditions, RSV metabolites function as a pool of RSV, actively contributing to a wide variety of actions, previously solely attributed to RSV.

\section{Resveratrol, Metabolic Health and Obesity}

Obesity is characterized by an excess accumulation of adipose tissue which is a risk factor for the development of chronic diseases [26,98]. Adipose tissue is composed of specialized cells, adipocytes, which store and release energy. To store energy, adipocytes convert free fatty acids to triglycerides through lipogenesis, and to release energy triglycerides are metabolized through a process called lipolysis. Adipocytes also produce hormones, adipokines, which relay information from the adipose tissue to the central nervous system [99]. Reduction of adipose tissue through increased physical activity and decreased energy intake can reduce the risk of adverse health outcomes. Though increased exercise and reduced calorie intake are effective methods to reduce adiposity, compliance is low and genetic factors may be unfavorable; therefore, alternative treatments are needed. RSV has been shown to influence adipose tissue function [100].

RSV was found to have an anti-lipolytic effect at low physiological concentration in a human adipocyte model [28]. A decreased sulfation of RSV, by knock-down of SULT1A1, resulted in an increased anti-lipolytic effect, as demonstrated by lower glycerol accumulation, probably attributed to lower activity of the lipolytic protein perilipin, suggesting the role of phase II enzymes in RSV bioavailability in adipose tissue. A comprehensive review on effects of RSV on adipose tissue [101] detailed effects on how RSV can modulate adipogenesis, apoptosis, de novo lipogenesis and lipoprotein lipase functions, lipolysis, thermogenesis, and fatty acid oxidation, in vitro and in rodent models.

Although adipose tissue is an attractive target site of RSV, only a few human studies have so far been conducted to consider RSV-treatment in this tissue. A recent human clinical trial investigated the effect of RSV supplementation on the adipose tissue metabolome [102]. In this study, male subjects with metabolic syndrome (characterized by elevations in at least three of the following: abdominal obesity, blood lipids, blood pressure and fasting blood glucose) were treated for four months with $1 \mathrm{~g}$ of resveratrol. The metabolome of these biological samples were characterized using untargeted metabolomics. This approach identified 282 metabolites in adipose tissue, of which 45 changed significantly in response to RSV treatment. RSV supplementation was associated with increased long chain-fatty acids, increased polyunsaturated fatty acids and decreased steroids [102]. Another study in obese men, supplemented for 30 days with $150 \mathrm{mg}$ of RSV, observed changes in adipose tissue morphology. RSV decreased abdominal subcutaneous adipocyte size. Transcriptome profiling on the adipose tissue samples and subsequent pathway analysis identified an enrichment of genes involved in cell cycle regulation pathways, suggesting enhanced adipogenesis [103].

In terms of obesity and the sphere of weight management, RSV has demonstrated significant improvement of glucose control and insulin sensitivity in diabetics [104]. A few studies indicate potential in enhancing adipogenesis as well as lipid markers in adipose tissue [102,103], therefore this is an application area worth further exploring. Even though clinical interventions can be particularly challenging, perhaps it is in the preventive health space that RSV can offer its full potential [31,78].

\section{Outlook}

With over 140 human clinical trials using RSV (clinicaltrials.gov), and more than 10,000 scientific publications describing the uses and effects of RSV, much research has been conducted on this small molecule. Due to varying doses, disparate experimental setups, low statistical power, and a myriad of biological or other types of confounders, the ultimate fate and effect of RSV in humans remains elusive. Mechanisms of action are varied and of potential benefit for cardiovascular health, obesity, metabolic health, inflammation, and cancer management, therefore, RSV is of wide pleiotropy. Systems-driven 
approaches [81] aid in mapping effects of multi-targeted compounds such as RSV and highlight links between bioenergetics [27], phase II metabolism [38] and redox pathways [93], linked by protein targets modulated by RSV.

The bioavailability of RSV is often mentioned as a limitation and is subject to controversy. Nevertheless, studies on RSV metabolites seem to be encouraging, as these either have similar effects or can act as a RSV pool in the body, fostering the metabolic effects previously solely attributed to free RSV [63]. On the note of enhancing knowledge on RSV metabolites and its potential actions, the use of untargeted metabolomics analysis [105] can widen the spectrum of RSV metabolites known so far, and also map metabolic sub-network effects induced by RSV [102]. Stable isotopes are an elegant tool to unravel metabolic fate of specific compounds [106] and offer advantages compared to radioactive labeling strategies.

Inter-individual variability [19] upon RSV intake can be attributed to various factors such as: (i) gut microbiota composition; (ii) genetic polymorphisms in phase II metabolism enzymes (e.g., UGTs, SULTs) and transporters, including tissue specificity and/or enzymatic regioselectivity; (iii) variability inherent in specific ethnicities or geographic subpopulations; (iv) specific lifestyles and diets; or (v) simply part of natural human variation. As bioactive-intervention studies often rely on small human studies, the variability can be overpowering. These factors need to be taken into account in future studies. Efforts to conduct larger and more deeply characterized studies could be an aim of the research community in order to bridge the current gaps in knowledge on RSV metabolism and beneficial effects.

Author Contributions: Both authors (M.S. and S.M.) conceptualized, wrote and approved the final version of this manuscript.

Funding: This research received no external funding.

Acknowledgments: S.M. is a participant in the EU-funded COST Action FA1403 POSITIVe (interindividual variation in response to consumption of plant food bioactives and determinants involved).

Conflicts of Interest: The authors are employees of Nestle Research.

\section{References}

1. Takaoka, M. The Phenolic Substances of White Hellebore (Veratrum Grandiflorum Hoes. Fil.) I. Nippon Kagaku Kaishi 1939, 60, 1090-1100. [CrossRef]

2. Siemann, E.H.; Creasy, L.L. Concentration Of The Phytoalexin Resveratrol In Wine. Am. J. Enol. Vitic. 1992, $43,49-52$.

3. St Leger, A.S.; Cochrane, A.; Moore, F. Factors Associated With Cardiac Mortality In Developed Countries With Particular Reference To The Consumption Of Wine. Lancet 1979, 313, 1017-1020. [CrossRef]

4. Renaud, S.; De Lorgeril, M. Wine, Alcohol, Platelets, And The French Paradox For Coronary Heart Disease. Lancet 1992, 339, 1523-1526. [CrossRef]

5. Frankel, E.N.; Waterhouse, A.L.; Kinsella, J.E. Inhibition Of Human Ldl Oxidation By Resveratrol. Lancet 1993, 341, 1103-1104. [CrossRef]

6. Jang, M.; Cai, L.; Udeani, G.O.; Slowing, K.V.; Thomas, C.F.; Beecher, C.W.W.; Fong, H.H.S.; Farnsworth, N.R.; Kinghorn, A.D.; Mehta, R.G.; et al. Cancer Chemopreventive Activity Of Resveratrol, A Natural Product Derived From Grapes. Science 1997, 275, 218-220. [CrossRef]

7. Subbaramaiah, K.; Chung, W.J.; Michaluart, P.; Telang, N.; Tanabe, T.; Inoue, H.; Jang, M.; Pezzuto, J.M.; Dannenberg, A.J. Resveratrol Inhibits Cyclooxygenase-2 Transcription And Activity In Phorbol Ester-Treated Human Mammary Epithelial Cells. J. Biol. Chem. 1998, 273, 21875-21882. [CrossRef]

8. Wallerath, T.; Deckert, G.; Ternes, T.; Anderson, H.; Li, H.; Witte, K.; Förstermann, U. Resveratrol, A Polyphenolic Phytoalexin Present In Red Wine, Enhances Expression And Activity Of Endothelial Nitric Oxide Synthase. Circulation 2002, 106, 1652-1658. [CrossRef]

9. Park, S.-J.; Ahmad, F.; Philp, A.; Baar, K.; Williams, T.; Luo, H.; Ke, H.; Rehmann, H.; Taussig, R.; Brown, A.L.; et al. Resveratrol Ameliorates Aging-Related Metabolic Phenotypes By Inhibiting Camp Phosphodiesterases. Cell 2012, 148, 421-433. [CrossRef] 
10. Howitz, K.T.; Bitterman, K.J.; Cohen, H.Y.; Lamming, D.W.; Lavu, S.; Wood, J.G.; Zipkin, R.E.; Chung, P.; Kisielewski, A.; Zhang, L.-L.; et al. Small Molecule Activators Of Sirtuins Extend Saccharomyces Cerevisiae Lifespan. Nature 2014, 19, 191-196. [CrossRef]

11. Baur, J.A.; Pearson, K.J.; Price, N.L.; Jamieson, H.A.; Lerin, C.; Kalra, A.; Prabhu, V.V.; Allard, J.S.; Lopez-Lluch, G.; Lewis, K.; et al. Resveratrol Improves Health And Survival Of Mice On A High-Calorie Diet. Nature 2006, 444, 337-342. [CrossRef] [PubMed]

12. Timmers, S.; Konings, E.; Bilet, L.; Houtkooper, R.H.; Van De Weijer, T.; Goossens, G.H.; Hoeks, J.; Van Der Krieken, S.; Ryu, D.; Kersten, S.; et al. Calorie Restriction-Like Effects Of 30 Days Of Resveratrol Supplementation On Energy Metabolism And Metabolic Profile In Obese Humans. Cell Metab. 2011, 14, 612-622. [CrossRef] [PubMed]

13. Lagouge, M.; Argmann, C.; Gerhart-Hines, Z.; Meziane, H.; Lerin, C.; Daussin, F.; Messadeq, N.; Milne, J.; Lambert, P.; Elliott, P.; et al. Resveratrol Improves Mitochondrial Function And Protects Against Metabolic Disease By Activating Sirt1 And Pgc-1 $\alpha$. Cell 2006, 127, 1109-1122. [CrossRef] [PubMed]

14. Baur, J.A.; Sinclair, D.A. Therapeutic Potential Of Resveratrol: The In Vivo Evidence. Nat. Rev. Drug Discov. 2006, 5, 493-506. [CrossRef]

15. Timmers, S.; De Ligt, M.; Phielix, E.; Van De Weijer, T.; Hansen, J.; Moonen-Kornips, E.; Schaart, G.; Kunz, I.; Hesselink, M.K.C.; Schrauwen-Hinderling, V.B.; et al. Resveratrol As Add-On Therapy In Subjects With Well-Controlled Type 2 Diabetes: A Randomized Controlled Trial. Diabetes Care 2016, 39, 2211-2217. [CrossRef] [PubMed]

16. Walle, T.; Hsieh, F.; Delegge, M.H.; John, E.; Oatis, J.; Walle, U.K. High Absorption But Very Low Bioavailability Of Oral Resveratrol In Humans. Drug Metab. Dispos. 2004, 32, 1377-1382. [CrossRef] [PubMed]

17. Yu, C.; Geun Shin, Y.; Chow, A.; Li, Y.; Kosmeder, J.W.; Sup Lee, Y.; Hirschelman, W.H.; Pezzuto, J.M.; Mehta, R.G.; Van Breemen, R.B. Human, Rat, And Mouse Metabolism Of Resveratrol. Pharm. Res. 2002, 19, 1907-1914. [CrossRef]

18. Böhmdorfer, M.; Szakmary, A.; Schiestl, R.; Vaquero, J.; Riha, J.; Brenner, S.; Thalhammer, T.; Szekeres, T.; Jäger, W. Involvement Of Udp-Glucuronosyltransferases And Sulfotransferases In The Excretion And Tissue Distribution Of Resveratrol In Mice. Nutrients 2017, 9, 1347. [CrossRef]

19. Manach, C.; Milenkovic, D.; Van De Wiele, T.; Rodriguez-Mateos, A.; De Roos, B.; Garcia-Conesa, M.T.; Landberg, R.; Gibney, E.R.; Heinonen, M.; Tomás-Barberán, F.; et al. Addressing The Inter-Individual Variation In Response To Consumption Of Plant Food Bioactives: Towards A Better Understanding Of Their Role In Healthy Aging And Cardiometabolic Risk Reduction. Mol. Nutr. Food Res. 2017, 61, 1600557. [CrossRef]

20. Bode, L.M.; Bunzel, D.; Huch, M.; Cho, G.; Ruhland, D.; Bunzel, M.; Bub, A.; Franz, C.M.; Kulling, S.E. In Vivo And In Vitro Metabolism Of Trans-Resveratrol By Human Gut Microbiota. Am. J. Clin. Nutr. 2013, 97, 295-309. [CrossRef]

21. Tomás-Barberán, F.A.; Selma, M.V.; Espín, J.C. Interactions Of Gut Microbiota With Dietary Polyphenols And Consequences To Human Health. Curr. Opin. Clin. Nutr. Metab. Care 2016, 19, 471-476. [CrossRef] [PubMed]

22. Ritter, J.K. Intestinal Ugts As Potential Modifiers Of Pharmacokinetics And Biological Responses To Drugs And Xenobiotics. Expert Opin. Drug Metab. Toxicol. 2007, 3, 93-107. [CrossRef] [PubMed]

23. Chen, B.-H.; Wang, C.-C.; Hou, Y.-H.; Mao, Y.-C.; Yang, Y.-S. Mechanism Of Sulfotransferase Pharmacogenetics In Altered Xenobiotic Metabolism. Expert Opin. Drug Metab. Toxicol. 2015, 11, 1053-1071. [CrossRef] [PubMed]

24. Lamba, J.K.; Lin, Y.S.; Schuetz, E.G.; Thummel, K.E. Genetic Contribution To Variable Human Cyp3a-Mediated Metabolism. Adv. Drug Deliv. Rev. 2012, 64, 256-269. [CrossRef]

25. Mena, P.; Del Rio, D. Gold Standards For Realistic (Poly)Phenol Research. J. Agric. Food Chem. 2018, 66, 8221-8223. [CrossRef] [PubMed]

26. Swinburn, B.A.; Sacks, G.; Hall, K.D.; Mcpherson, K.; Finegood, D.T.; Moodie, M.L.; Gortmaker, S.L. The Global Obesity Pandemic: Shaped By Global Drivers And Local Environments. Lancet 2011, 378, 804-814. [CrossRef]

27. Tseng, Y.H.; Cypess, A.M.; Kahn, C.R. Cellular Bioenergetics As A Target For Obesity Therapy. Nat. Rev. Drug Discov. 2010, 9, 465-481. [CrossRef] [PubMed] 
28. Gheldof, N.; Moco, S.; Chabert, C.; Teav, T.; Barron, D.; Hager, J. Role Of Sulfotransferases In Resveratrol Metabolism In Human Adipocytes. Mol. Nutr. Food Res. 2017, 61, 1700020. [CrossRef]

29. Jimenez-Gomez, Y.; Mattison, J.A.; Pearson, K.J.; Martin-Montalvo, A.; Palacios, H.H.; Sossong, A.M.; Ward, T.M.; Younts, C.M.; Lewis, K.; Allard, J.S.; et al. Resveratrol Improves Adipose Insulin Signaling And Reduces The Inflammatory Response In Adipose Tissue Of Rhesus Monkeys On High-Fat, High-Sugar Diet. Cell Metab. 2013, 18, 533-545. [CrossRef]

30. Burns, J.; Yokota, T.; Ashihara, H.; Lean, M.E.J.; Crozier, A. Plant Foods And Herbal Sources Of Resveratrol. J. Agric. Food Chem. 2002, 50, 3337-3340. [CrossRef]

31. Pezzuto, J.M. Resveratrol: Twenty Years Of Growth, Development And Controversy. Biomol. Ther. 2018, 14, 1-14. [CrossRef] [PubMed]

32. Planas, J.M.; Alfaras, I.; Colom, H.; Juan, M.E. The Bioavailability And Distribution Of Trans-Resveratrol Are Constrained By Abc Transporters. Arch. Biochem. Biophys. 2012, 527, 67-73. [CrossRef] [PubMed]

33. Henry, C.; Vitrac, X.; Decendit, A.; Ennamany, R.; Krisa, S.; Mérillon, J.-M. Cellular Uptake And Efflux Of Trans -Piceid And Its Aglycone Trans -Resveratrol On The Apical Membrane Of Human Intestinal Caco-2 Cells. J. Agric. Food Chem. 2005, 53, 798-803. [CrossRef] [PubMed]

34. Riches, Z.; Stanley, E.L.; Bloomer, J.C.; Coughtrie, M.W.H. Quantitative Evaluation Of The Expression And Activity Of Five Major Sulfotransferases (Sults) In Human Tissues: The Sult "Pie". Drug Metab. Dispos. 2009, 37, 2255-2261. [CrossRef] [PubMed]

35. Ung, D.; Nagar, S. Variable Sulfation Of Dietary Polyphenols By Recombinant Human Sulfotransferase (Sult) 1a1 Genetic Variants And Sult1e1. Drug Metab. Dispos. 2007, 35, 740-746. [CrossRef] [PubMed]

36. Miksits, M.; Maier-Salamon, A.; Aust, S.; Thalhammer, T.; Reznicek, G.; Kunert, O.; Haslinger, E.; Szekeres, T.; Jaeger, W. Sulfation Of Resveratrol In Human Liver: Evidence Of A Major Role For The Sulfotransferases Sult1a1 And Sult1e1. Xenobiotica 2005, 35, 1101-1119. [CrossRef] [PubMed]

37. Oda, S.; Fukami, T.; Yokoi, T.; Nakajima, M. A Comprehensive Review Of Udp-Glucuronosyltransferase And Esterases For Drug Development. Drug Metab. Pharmacokinet. 2015, 30, 30-51. [CrossRef]

38. Rouleau, M.M.; Audet-Delage, Y.; Desjardins, S.; Rouleau, M.M.; Girard-Bock, C.; Guillemette, C. Endogenous Protein Interactome Of Human Udp-Glucuronosyltransferases Exposed By Untargeted Proteomics. Front. Pharmacol. 2017, 8, 23. [CrossRef]

39. Dietrich, C.G.; Geier, A.; Oude Elferink, R.P.J. Abc Of Oral Bioavailability: Transporters As Gatekeepers In The Gut. Gut 2003, 52, 1788-1795. [CrossRef]

40. Maier-Salamon, A.; Böhmdorfer, M.; Riha, J.; Thalhammer, T.; Szekeres, T.; Jaeger, W. Interplay Between Metabolism And Transport Of Resveratrol. Ann. N. Y. Acad. Sci. 2013, 1290, 98-106. [CrossRef]

41. Vitaglione, P.; Sforza, S.; Galaverna, G.; Ghidini, C.; Caporaso, N.; Vescovi, P.P.; Fogliano, V.; Marchelli, R. Bioavailability Of Trans-Resveratrol From Red Wine In Humans. Mol. Nutr. Food Res. 2005, 49, 495-504. [CrossRef] [PubMed]

42. Patel, K.R.; Scott, E.; Brown, V.A.; Gescher, A.J.; Steward, W.P.; Brown, K. Clinical Trials Of Resveratrol. Ann. N. Y. Acad. Sci. 2011, 1215, 161-169. [CrossRef] [PubMed]

43. Marier, J.-F. Metabolism And Disposition Of Resveratrol In Rats: Extent Of Absorption, Glucuronidation, And Enterohepatic Recirculation Evidenced By A Linked-Rat Model. J. Pharmacol. Exp. Ther. 2002, 302, 369-373. [CrossRef] [PubMed]

44. Asensi, M.; Medina, I.; Ortega, A.; Carretero, J.; Baño, M.C.; Obrador, E.; Estrela, J.M. Inhibition Of Cancer Growth By Resveratrol Is Related To Its Low Bioavailability. Free Radic. Biol. Med. 2002, 33, 387-398. [CrossRef]

45. Emília Juan, M.; Buenafuente, J.; Casals, I.; Planas, J.M. Plasmatic Levels Of Trans-Resveratrol In Rats. Food Res. Int. 2002, 35, 195-199. [CrossRef]

46. Menet, M.-C.; Baron, S.; Taghi, M.; Diestra, R.; Dargère, D.; Laprévote, O.; Nivet-Antoine, V.; Beaudeux, J.-L.; Bédarida, T.; Cottart, C.-H. Distribution Of Trans -Resveratrol And Its Metabolites After Acute Or Sustained Administration In Mouse Heart, Brain, And Liver. Mol. Nutr. Food Res. 2017, 61, 1600686. [CrossRef] [PubMed]

47. Andres-Lacueva, C.; Macarulla, M.T.; Rotches-Ribalta, M.; Boto-Ordóñez, M.; Urpi-Sarda, M.; Rodríguez, V.M.; Portillo, M.P. Distribution Of Resveratrol Metabolites In Liver, Adipose Tissue, And Skeletal Muscle In Rats Fed Different Doses Of This Polyphenol. J. Agric. Food Chem. 2012, 60, 4833-4840. [CrossRef] 
48. Alberdi, G.; Rodríguez, V.M.; Miranda, J.; Macarulla, M.T.; Arias, N.; Andrés-Lacueva, C.; Portillo, M.P. Changes In White Adipose Tissue Metabolism Induced By Resveratrol In Rats. Nutr. Metab. 2011, 8, 29. [CrossRef]

49. Burkon, A.; Somoza, V. Quantification Of Free And Protein-Boundtrans-Resveratrol Metabolites And Identification Oftrans-Resveratrol-C/O-Conjugated Diglucuronides-Two Novel Resveratrol Metabolites In Human Plasma. Mol. Nutr. Food Res. 2008, 52, 549-557. [CrossRef]

50. Selma, M.V.; Espín, J.C.; Tomás-Barberán, F.A. Interaction Between Phenolics And Gut Microbiota: Role In Human Health. J. Agric. Food Chem. 2009, 57, 6485-6501. [CrossRef]

51. Dao, T.-M.A.; Waget, A.; Klopp, P.; Serino, M.; Vachoux, C.; Pechere, L.; Drucker, D.J.; Champion, S.; Barthélemy, S.; Barra, Y.; et al. Resveratrol Increases Glucose Induced Glp-1 Secretion In Mice: A Mechanism Which Contributes To The Glycemic Control. PLoS ONE 2011, 6, E20700. [CrossRef]

52. Larrosa, M.; Gonza, A.; Toti, S.; Joaqui, J.; Yañéz-Gascón, M.J.; Selma, M.V.; González-Sarrías, A.; Toti, S.; Cerón, J.J.; Tomás-Barberán, F.; et al. Effect Of A Low Dose Of Dietary Resveratrol On Colon Microbiota, Inflammation And Tissue Damage In A Dss-Induced Colitis Rat Model. J. Agric. Food Chem. 2009, 57, 2211-2220. [CrossRef] [PubMed]

53. Hwang, D.; Lim, Y.-H. Resveratrol Antibacterial Activity Against Escherichia Coli Is Mediated By Z-Ring Formation Inhibition Via Suppression Of Ftsz Expression. Sci. Rep. 2015, 5, 10029. [CrossRef]

54. Paulo, L.; Ferreira, S.; Gallardo, E.; Queiroz, J.A.; Domingues, F. Antimicrobial Activity And Effects Of Resveratrol On Human Pathogenic Bacteria. World J. Microbiol. Biotechnol. 2010, 26, 1533-1538. [CrossRef]

55. Sung, M.M.; Kim, T.T.; Denou, E.; Soltys, C.-L.M.; Hamza, S.M.; Byrne, N.J.; Masson, G.; Park, H.; Wishart, D.S.; Madsen, K.L.; et al. Improved Glucose Homeostasis In Obese Mice Treated With Resveratrol Is Associated With Alterations In The Gut Microbiome. Diabetes 2017, 66, 418-425. [CrossRef] [PubMed]

56. Ley, R.E.; Bäckhed, F.; Turnbaugh, P.; Lozupone, C.A.; Knight, R.D.; Gordon, J.I. Obesity Alters Gut Microbial Ecology. Proc. Natl. Acad. Sci. USA 2005, 102, 11070-11075. [CrossRef]

57. Etxeberria, U.; Arias, N.; Boqué, N.; Macarulla, M.T.; Portillo, M.P.; Martínez, J.A.; Milagro, F.I. Reshaping Faecal Gut Microbiota Composition By The Intake Of. J. Nutr. Biochem. 2015, 26, 1-26. [CrossRef]

58. Bird, J.K.; Raederstorff, D.; Weber, P.; Steinert, R.E. Cardiovascular And Antiobesity Effects Of Resveratrol Mediated Through The Gut Microbiota. Adv. Nutr. 2017, 8, 839-849. [CrossRef]

59. Most, J.; Penders, J.; Lucchesi, M.; Goossens, G.H.; Blaak, E.E. Gut Microbiota Composition In Relation To The Metabolic Response To 12-Week Combined Polyphenol Supplementation In Overweight Men And Women. Eur. J. Clin. Nutr. 2017, 71, 1040-1045. [CrossRef]

60. Koeth, R.A.; Wang, Z.; Levison, B.S.; Buffa, J.A.; Org, E.; Sheehy, B.T.; Britt, E.B.; Fu, X.; Wu, Y.; Li, L.; et al. Intestinal Microbiota Metabolism Of L-Carnitine, A Nutrient In Red Meat, Promotes Atherosclerosis. Nat. Med. 2013, 19, 576-585. [CrossRef]

61. Chen, M.; Yi, L.; Zhang, Y.; Zhou, X.; Ran, L.; Yang, J.; Zhu, J.; Zhang, Q.; Mi, M. Atherosclerosis By Regulating Tmao Synthesis And Bile Acid Metabolism Via Remodeling Of The Gut Microbiota. Mbio 2016, 7, E02210-E02215. [CrossRef] [PubMed]

62. Juan, M.E.; González-Pons, E.; Planas, J.M. Multidrug Resistance Proteins Restrain The Intestinal Absorption Of Trans-Resveratrol In Rats. J. Nutr. 2010, 140, 489-495. [CrossRef] [PubMed]

63. Patel, K.R.; Andreadi, C.; Britton, R.G.; Horner-Glister, E.; Karmokar, A.; Sale, S.; Brown, V.A.; Brenner, D.E.; Singh, R.; Steward, W.P.; et al. Sulfate Metabolites Provide An Intracellular Pool For Resveratrol Generation And Induce Autophagy With Senescence. Sci. Transl. Med. 2013, 5. [CrossRef] [PubMed]

64. Cottart, C.; Nivet-Antoine, V.; Laguillier-Morizot, C.; Beaudeux, J. Resveratrol Bioavailability And Toxicity In Humans. Mol. Nutr. Food Res. 2010, 54, 7-16. [CrossRef] [PubMed]

65. Sergides, C.; Chirilă, M.; Silvestro, L.; Pitta, D.; Pittas, A. Bioavailability And Safety Study Of Resveratrol 500 Mg Tablets In Healthy Male And Female Volunteers. Exp. Ther. Med. 2016, 11, 164-170. [CrossRef] [PubMed]

66. Novotny, J.A.; Chen, T.-Y.; Terekhov, A.I.; Gebauer, S.K.; Baer, D.J.; Ho, L.; Pasinetti, G.M.; Ferruzzi, M.G. The Effect Of Obesity And Repeated Exposure On Pharmacokinetic Response To Grape Polyphenols In Humans. Mol. Nutr. Food Res. 2017, 61, 1700043. [CrossRef] [PubMed]

67. Wightman, E.L.; Haskell-Ramsay, C.F.; Reay, J.L.; Williamson, G.; Dew, T.; Zhang, W.; Kennedy, D.O. The Effects Of Chronic Trans-Resveratrol Supplementation On Aspects Of Cognitive Function, Mood, Sleep, Health And Cerebral Blood Flow In Healthy, Young Humans. Br. J. Nutr. 2015, 114, 1427-1437. [CrossRef] 
68. Kennedy, D.O.; Wightman, E.L.; Reay, J.L.; Lietz, G.; Okello, E.J.; Wilde, A.; Haskell, C.F. Effects Of Resveratrol On Cerebral Blood Flow Variables And Cognitive Performance In Humans: A Double-Blind, Placebo-Controlled, Crossover Investigation. Am. J. Clin. Nutr. 2010, 91, 1590-1597. [CrossRef]

69. Blanchard, O.L.; Friesenhahn, G.; Javors, M.A.; Smoliga, J.M. Development Of A Lozenge For Oral Transmucosal Delivery Of Trans-Resveratrol In Humans: Proof Of Concept. PLoS ONE 2014, 9. [CrossRef]

70. Draijer, R.; Van Dorsten, F.A.; Zebregs, Y.E.; Hollebrands, B.; Peters, S.; Duchateau, G.S.; Grün, C.H. Impact Of Proteins On The Uptake, Distribution, And Excretion Of Phenolics In The Human Body. Nutrients 2016, 8 , 814. [CrossRef]

71. Brown, V.A.; Patel, K.R.; Viskaduraki, M.; Crowell, J.A.; Perloff, M.; Booth, T.D.; Vasilinin, G.; Sen, A.; Schinas, A.M.; Piccirilli, G.; et al. Repeat Dose Study Of The Cancer Chemopreventive Agent Resveratrol In Healthy Volunteers: Safety, Pharmacokinetics, And Effect On The Insulin-Like Growth Factor Axis. Cancer Res. 2010, 70, 9003-9011. [CrossRef] [PubMed]

72. Howells, L.M.; Berry, D.P.; Elliott, P.J.; Jacobson, E.W.; Hoffmann, E.; Hegarty, B.; Brown, K.; Steward, W.P.; Gescher, A.J. Phase I Randomized, Double-Blind Pilot Study Of Micronized Resveratrol (Srt501) In Patients With Hepatic Metastases-Safety, Pharmacokinetics, And Pharmacodynamics. Cancer Prev. Res. 2011, 4, 1419-1425. [CrossRef] [PubMed]

73. La Porte, C.; Voduc, N.; Zhang, G.; Seguin, I.; Tardiff, D.; Singhal, N.; Cameron, D.W. Steady-State Pharmacokinetics And Tolerability Of Trans-Resveratrol 2000mg Twice Daily With Food, Quercetin And Alcohol (Ethanol) In Healthy Human Subjects. Clin. Pharmacokinet. 2010, 49, 449-454. [CrossRef] [PubMed]

74. Wong, R.H.X.; Howe, P.R.C.; Buckley, J.D.; Coates, A.M.; Kunz, I.; Berry, N.M. Acute Resveratrol Supplementation Improves Flow-Mediated Dilatation In Overweight/Obese Individuals With Mildly Elevated Blood Pressure. Nutr. Metab. Cardiovasc. Dis. 2011, 21, 851-856. [CrossRef] [PubMed]

75. Kulkarni, S.S.; Cantó, C. The Molecular Targets Of Resveratrol. Biochim. Biophys. Acta Mol. Basis Dis. 2015, 1852, 1114-1123. [CrossRef] [PubMed]

76. Pervaiz, S.; Holme, A.L. Resveratrol: Its Biologic Targets And Functional Activity. Antioxid. Redox Signal. 2009, 11, 2851-2897. [CrossRef] [PubMed]

77. Britton, R.G.; Kovoor, C.; Brown, K. Direct Molecular Targets Of Resveratrol: Identifying Key Interactions To Unlock Complex Mechanisms. Ann. N. Y. Acad. Sci. 2015, 1348, 124-133. [CrossRef]

78. Vang, O. Resveratrol: Challenges In Analyzing Its Biological Effects. Ann. N. Y. Acad. Sci. 2015, 1348, 161-170. [CrossRef]

79. Dolinsky, V.W.; Dyck, J.R.B. Calorie Restriction And Resveratrol In Cardiovascular Health And Disease. Biochim. Biophys. Acta Mol. Basis Dis. 2011, 1812, 1477-1489. [CrossRef]

80. Tomé-Carneiro, J.; Larrosa, M.; González-Sarrías, A.; Tomás-Barberán, F.; García-Conesa, M.; Espín, J. Resveratrol And Clinical Trials: The Crossroad From In Vitro Studies To Human Evidence. Curr. Pharm. Des. 2013, 19, 6064-6093. [CrossRef]

81. Lacroix, S.; Klicic Badoux, J.; Scott-Boyer, M.-P.; Parolo, S.; Matone, A.; Priami, C.; Morine, M.J.; Kaput, J.; Moco, S. A Computationally Driven Analysis Of The Polyphenol-Protein Interactome. Sci. Rep. 2018, 8, 2232. [CrossRef] [PubMed]

82. Huang, D.W.; Sherman, B.T.; Tan, Q.; Kir, J.; Liu, D.; Bryant, D.; Guo, Y.; Stephens, R.; Baseler, M.W.; Lane, H.C.; Lempicki, R.A. David Bioinformatics Resources: Expanded Annotation Database And Novel Algorithms To Better Extract Biology From Large Gene Lists. Nucleic Acids Res. 2007, 35, 169-175. [CrossRef] [PubMed]

83. Becker, K.G.; Barnes, K.C.; Bright, T.J.; Wang, S.A. The Genetic Association Database. Nat. Genet. 2004, 36, 431-432. [CrossRef]

84. Finn, R.D.; Attwood, T.K.; Babbitt, P.C.; Bateman, A.; Bork, P.; Bridge, A.J.; Chang, H.-Y.; Dosztányi, Z.; El-Gebali, S.; Fraser, M.; et al. Interpro In 2017-Beyond Protein Family And Domain Annotations. Nucleic Acids Res. 2017, 45, D190-D199. [CrossRef] [PubMed]

85. Kuhn, M.; Von Mering, C.; Campillos, M.; Jensen, L.J.; Bork, P. Stitch: Interaction Networks Of Chemicals And Proteins. Nucleic Acids Res. 2008, 36, 684-688. [CrossRef] [PubMed]

86. Berman, H.M.; Westbrook, J.; Feng, Z.; Gilliland, G.; Bhat, T.N.; Weissig, H.; Shindyalov, I.N.; Bourne, P.E. The Protein Data Bank. Nucleic Acids Res. 2000, 28, 235-242. [CrossRef] [PubMed]

87. Houtkooper, R.H.; Pirinen, E.; Auwerx, J. Sirtuins As Regulators Of Metabolism And Healthspan. Nat. Rev. Mol. Cell Biol. 2012, 13, 225-238. [CrossRef] 
88. Xia, N.; Förstermann, U.; Li, H. Effects Of Resveratrol On Enos In The Endothelium And The Perivascular Adipose Tissue. Ann. N. Y. Acad. Sci. 2017, 1403, 132-141. [CrossRef]

89. Szklarczyk, D.; Santos, A.; Von Mering, C.; Jensen, L.J.; Bork, P.; Kuhn, M. Stitch 5: Augmenting Protein-Chemical Interaction Networks With Tissue And Affinity Data. Nucleic Acids Res. 2016, 44, D380-D384. [CrossRef]

90. Portela, A.; Esteller, M. Epigenetic Modifications And Human Disease. Nat. Biotechnol. 2010, 28 , 1057. [CrossRef]

91. Kemper, J.K.; Xiao, Z.; Ponugoti, B.; Miao, J.; Fang, S.; Kanamaluru, D.; Tsang, S.; Wu, S.; Chiang, C.; Veenstra, T.D. Fxr Acetylation Is Normally Dynamically Regulated By P300 And Sirt1 But Constitutively Elevated In Metabolic Disease States. Cell Metab. 2009, 10, 392-404. [CrossRef] [PubMed]

92. Keylor, M.H.; Matsuura, B.S.; Stephenson, C.R.J. Chemistry And Biology Of Resveratrol-Derived Natural Products. Chem. Rev. 2015, 115, 8976-9027. [CrossRef] [PubMed]

93. Hayes, J.D.; Dinkova-Kostova, A.T. The Nrf2 Regulatory Network Provides An Interface Between Redox And Intermediary Metabolism. Trends Biochem. Sci. 2014, 39, 199-218. [CrossRef] [PubMed]

94. Erlank, H.; Elmann, A.; Kohen, R.; Kanner, J. Polyphenols Activate Nrf2 In Astrocytes Via H2o2, Semiquinones, And Quinones. Free Radic. Biol. Med. 2011, 51, 2319-2327. [CrossRef]

95. Seyyedebrahimi, S.; Khodabandehloo, H.; Nasli Esfahani, E.; Meshkani, R. The Effects Of Resveratrol On Markers Of Oxidative Stress In Patients With Type 2 Diabetes: A Randomized, Double-Blind, Placebo-Controlled Clinical Trial. Acta Diabetol. 2018, 55, 341-353. [CrossRef] [PubMed]

96. Calamini, B.; Ratia, K.; Malkowski, M.G.; Cuendet, M.; Pezzuto, J.M.; Santarsiero, B.D.; Mesecar, A.D. Pleiotropic Mechanisms Facilitated By Resveratrol And Its Metabolites. Biochem. J. 2010, 429, $273-282$. [CrossRef] [PubMed]

97. Lu, D.L.; Ding, D.J.; Yan, W.J.; Li, R.R.; Dai, F.; Wang, Q.; Yu, S.S.; Li, Y.; Jin, X.L.; Zhou, B. Influence Of Glucuronidation And Reduction Modifications Of Resveratrol On Its Biological Activities. Chembiochem 2013, 14, 1094-1104. [CrossRef] [PubMed]

98. Hruby, A.; Hu, F.B. The Epidemiology Of Obesity: A Big Picture. Pharmacoeconomics 2015, 33, 673-689. [CrossRef]

99. Sethi, J.K.; Vidal-Puig, A.J. Thematic Review Series: Adipocyte Biology. Adipose Tissue Function And Plasticity Orchestrate Nutritional Adaptation. J. Lipid Res. 2007, 48, 1253-1262. [CrossRef]

100. Maclean, P.S.; Higgins, J.A.; Giles, E.D.; Sherk, V.D.; Jackman, M.R. The Role For Adipose Tissue In Weight Regain After Weight Loss. Obes. Rev. 2015, 16, 45-54. [CrossRef]

101. Aguirre, L.; Fernández-Quintela, A.; Arias, N.; Portillo, M. Resveratrol: Anti-Obesity Mechanisms Of Action. Molecules 2014, 19, 18632-18655. [CrossRef]

102. Korsholm, A.; Kjær, T.; Ornstrup, M.; Pedersen, S. Comprehensive Metabolomic Analysis In Blood, Urine, Fat, And Muscle In Men With Metabolic Syndrome: A Randomized, Placebo-Controlled Clinical Trial On The Effects Of Resveratrol After Four Months' Treatment. Int. J. Mol. Sci. 2017, 18, 554. [CrossRef]

103. Konings, E.; Timmers, S.; Boekschoten, M.V.; Goossens, G.H.; Jocken, J.W.; Afman, L.A.; Müller, M.; Schrauwen, P.; Mariman, E.C.; Blaak, E.E. The Effects Of 30 Days Resveratrol Supplementation On Adipose Tissue Morphology And Gene Expression Patterns In Obese Men. Int. J. Obes. 2014, 38, 470-473. [CrossRef]

104. Liu, K.; Zhou, R.; Wang, B.; Mi, M. Effect Of Resveratrol On Glucose Control And Insulin Sensitivity: A Meta-Analysis Of 11 Randomized Controlled Trials. Am. J. Clin. Nutr. 2014, 99, 1510-1519. [CrossRef]

105. Moco, S.; Bino, R.J.; De Vos, R.C.H.; Vervoort, J. Metabolomics Technologies And Metabolite Identification. Trends Analaytical Chem. 2007, 26, 1694-1703. [CrossRef]

106. Naranjo Pinta, M.; Montoliu, I.; Aura, A.-M.; Seppänen-Laakso, T.; Barron, D.; Moco, S. In Vitro Gut Metabolism Of [U-13 C]-Quinic Acid, The Other Hydrolysis Product Of Chlorogenic Acid. Mol. Nutr. Food Res. 2018, 1800396. [CrossRef]

(C) 2019 by the authors. Licensee MDPI, Basel, Switzerland. This article is an open access article distributed under the terms and conditions of the Creative Commons Attribution (CC BY) license (http:/ / creativecommons.org/licenses/by/4.0/). 